\title{
CONNECTIVITY BEYOND BORDERS IN DOMNICA RĂDULESCU'S TRAIN TO TRIESTE
}

\author{
CONNECTIVITÉ AU-DELÀ DES FRONTIÈRES DANS \\ LE ROMAN UN TRAIN POUR TRIESTE DE DOMNICA \\ RĂDULESCU
}

\author{
Adriana Elena STOICAN 1 \\ https://doi.org/10.52744/9786062613242.20
}

\begin{abstract}
The novel Train to Trieste by Domnica Rădulescu features the role played by transnational channels of communication in maintaining connections across physical and temporal borders between Romania and America. The discussion will focus on the particular networks employed by the protagonist Mona Manoliu (letters, phone calls, radio/TV transmissions) in order to transcend the alienating effects of exile in America. The argument combines a cultural studies approach with a close reading of the text, seeking to establish the manner in which contemporary fiction of migration presents the impact of linear transnationalism upon Romanian political refugees and their families.
\end{abstract}

Keywords: Borders; Diaspora; Exile; Letters; Radio; Travel; Television; Transnationalism

Résumé : Le roman Un train pour Trieste de Domnica Rădulescu montre le rôle joué par les canaux de communication transnationaux dans le maintien des connexions à travers les frontières physiques et temporelles entre la Roumanie et l'Amérique. Il s'agira dans cet article d'examiner les réseaux particuliers employés par la protagoniste Mona Manoliu (lettres, appels téléphoniques, transmissions radio/TV) pour transcender les effets aliénants de l'exil en Amérique. L'analyse recourt aux approches des études culturelles et les combine avec une lecture attentive du texte, cherchant à établir la manière dont la fiction contemporaine de la migration présente l'impact du transnationalisme linéaire sur les réfugiés politiques roumains et leurs familles.

Mots-clés : Frontières ; Diaspora ; Exil ; Lettres ; Radio ; Voyages ; Télévision ; Transnationalisme.

1 Assistant professor, PhD., Bucharest University of Economic Studies, Email adriana.stoican@rei.ase.ro 


\section{Domnica RĂDULESCU, author's background}

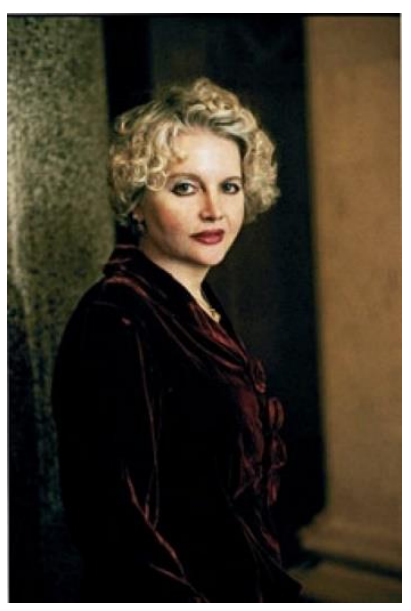

Domnica Rădulescu² is an American author of Romanian origin, whose writings, Train to Trieste (2008), Black Sea Twilight (2010), Country of Red Azaleas (2016) have received extremely positive reviews. She has worked in the theater, directed numerous plays, and is the founding director of The National Symposium of Theater in Academe. She has also edited collections on theater, East European literature, exile literature, representations of women, and humor. The predominant themes of her fictional universe are exile, women's solidarity and empowerment, transcultural identities, nomadic itineraries and transnational mobility. Holder of a BA degree with a Major in English literature and civilization from the University of Bucharest, she left Romania in 1983. Among the reasons for her defection, Radulescu mentions the desire to fulfill her dreams of becoming a writer and professor, the unwillingness to make compromises in communist Romania, and the urge to discover the world (Rădulescu in Flacăra Interview). Besides being a successful writer, Rădulescu is also a Professor of comparative literature (French and Italian) at Washington and Lee University, Virginia, where she has taught since 1992. She is Chair of the Women's and Gender Studies Program at the same university.

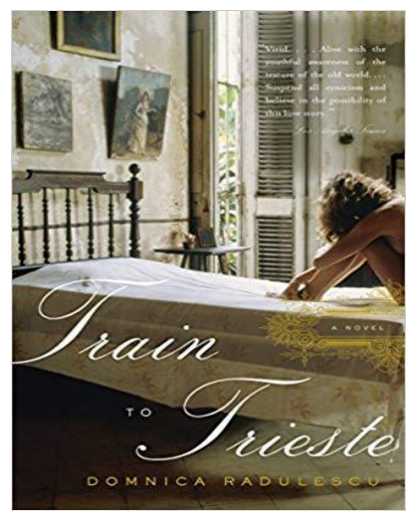

Train to Trieste 3 is a work of fiction inspired by Rădulescu's background of migration. It won the Library of Virginia Prize for the category Best Fiction. It presents the life trajectory of Mona Manoliu, a girl raised in communist Bucharest, who escapes Ceauşescu's dictatorship in the early 1980's. Despite her intense passion for her lover Mihai, whom she meets in the city of Braşov, she decides to leave Romania, fearing for her safety in a country surveilled by the Secret Police. After a short transit through Belgrade, Mona crosses the Italian border illegally, pretending to be the wife

2 Photo retrieved from: https://www.feminis.ro/domnica-radulescu-premiata-in-suapentru-romanul-sau-de-debut_4712.html\#n

3 Cover retrieved from Source: https://www.amazon.com/Train-Trieste-DomnicaRadulescu/dp/o307388360 
of an Italian man, Mario. She spends her first two weeks in Italy as a guest of Mario's family in Trieste. The following episode of Mona's migratory experience unfolds in Rome, the city where she is hosted by Mario and his wife's friends (Marina, Vittorio and their daughter Roxana). Although she loves Rome, Mona is determined to apply for refugee status in the United States; therefore, she experiences another relocation episode, this time from Europe to America. Mona's life in America represents a chain of events that mark her gradual familiarization with the new country along the lines of successful integration: marriage, divorce, the birth of two sons and her becoming an academic. However, she is torn by her longing for Romania, missing her parents and being haunted by the memories of her relationship with Mihai. After the political events of 1989, Mona is free to revisit her native country and find out whether she can resume her love story with Mihai and build a transnational identity so as to embrace both her Romanian past and her American experience.

By contrast, Rădulescu's second novel, Black Sea Twilight does not include America as a destination for the relocation of the Romanian characters. The plot initially unfolds in the Romanian town of Mangalia, a few years before the Romanian revolution. The protagonist is a young woman, Nora Teodoru, who dreams of becoming a visual artist, while falling in love with Gigi, a young man of Turkish ethnicity. Like Mona Manoliu, Nora is gradually suffocated by Ceauşescu's oppressive regime and she eventually defects to Turkey (Istanbul); after some time, she manages to settle in Paris. Also, as in Train to Trieste, Black Sea Twilight presents women's migration as a transcultural journey, given that Nora also traverses multiple cultural spaces. Interestingly, the novel offers numerous details about daily life/practices in communist Romania, foregrounding its multicultural profile and possibilities of inter-ethnic cohabitation.

The author's third novel, Country of Red Azaleas, departs from the problematics of Romanian female migration but develops the theme of women's solidarity in the context of transnational relocation and national division. The novel features the friendship between a Bosnian and a Serbian woman, Marija and Lara, tracing the dynamics of this relationship in the context of the Bosnian War. Notwithstanding the enmity between their native lands, the protagonists' choices prove that human bonds have the power to defy national allegiance and political orientations.

\section{Aims}

The present paper focuses on Train to Trieste, outlining particular mechanisms of transnational communication that allow the maintenance of meaningful connections between Mona Manoliu and her homeland. The discussion relies on a cultural studies approach to literature, that 
considers the literary text as a witness and a repository of cultural experiences in the context of Romanian women's relocation. This perspective is combined with a close reading of the primary text. More specifically, the discussion sets out to foreground the interplay of exilic longing and transnational connectivity afforded by communication technologies available to Romanian refugees before 1989. As background, I will first discuss several perspectives regarding Romanian emigration to the West as well as theoretical approaches to diaspora/exile and transnational migration.

\section{Patterns of Romanian emigration}

Romanian emigration to the West has been described as a layered phenomenon, whose stages entailed different motivations and specific destinations. In Captiv în Lumea Liberă, Theodor Cazaban (2002) discusses Mircea Eliade's account of the Romanian westward migration, presented as a two-stage process. The first wave, between the 1940's and 1950's, characterized by its uniformity and solidarity, comprised Romanian refugees who settled in France, Spain and America. They were fleeing the Stalinist regime and they aimed to inform the West about the historical realities of Romania's oppression. At the same time, they focused on preserving and disseminating Romanian cultural values in the West. The second wave of emigrants, dating back to the 1970's, was trying to escape Ceauşescu's regime of persecution and regarded the West as a space of liberation.

Eva Behring (2001) discusses Romanian post-war migration in terms of three waves: 1940-50's, 1960's-70's and the 1980's, each triggered by a wide range of push factors: political persecution, discrimination, jail threats, interdictions on publishing, censorship (Behring quoted in Oprescu-Şerban et al. 2012, 47). Analyzing specific examples of Romanian international mobility before 1989, Croitoru identifies two distinct situations: permanent migrants who were forced to leave Romania in order to avoid communist persecution and persons who could travel to other communist destinations approved by the communist regime. Individuals belonging to the second category were carefully selected by the Romanian Security Department and they could only travel in groups so that they could be easily supervised and prevented from defecting (Croitoru et al. 2014, 32-33). It seems that the main trigger for Romanians travelling abroad before 1989 was the search for freedom and the desire to escape an imprisoning homeland (Croitoru 29). Considering the socio-political specificity of the Romanian context, one may place Domnica Rădulescu in the 1980's category of illegal immigrants who were looking for independence beyond the Iron Curtain. 


\section{Transnational perspectives}

Transnationalism is envisaged here as a critical framework for the naturalized frame of the nation (Briggs et al. 2008, 3). As a general term, it refers to cross-border relationships, patterns of exchange, affiliations and social formations straddling nation-states. Transnationalism is facilitated by globalization, designating manners in which developments in transportation, technology and communication have accelerated the speed, intensity and impact of various linkages (Vertovec 2009, 2). The cultural studies approach interprets transnationalism as a special type of consciousness generated by individuals' multiple identifications, decentered attachments and simultaneous being here and there (Vertovec 2009, 5, 6). Transnationalism is associated with a mode of cultural reproduction that relies on intersection of cultural patterns. These processes of cultural blending have been described by various terms (creolization, syncretism, bricolage, cultural translation, hybridity) and have been analyzed in relation with global media (television, music, film, visual arts, diasporic literature) and communication (Vertovec 2009, 7). The language employed to characterize the transnational moment relies on concepts such as homelessness, hybridity, and plurality, while the contemporary diasporic groups are defined as "the exemplary communities of the transnational moment" (Tololyan 1996, 4). Similarly, Ong defines transnationality as the accelerated rhythm of cultural intersections that shapes individuals' mobility within the regime of late capitalism. Thus, the transnational paradigm renders the sense of dynamism and change triggered by the movement through space or across lines:

By suggesting new relations between nations and capital, transnationality also alludes to the transversal, the transactional, the translational, and the transgressive aspects of contemporary behavior and imagination [...] regulated by the changing logic of states and capitalism (Ong 2006, 4).

Therefore, transnationalism carries a transgressive connotation resulting from the interaction of capitalist forces with national borders. Hannerz considers that the main consequence of transnationalism is the "weakened personal involvement with the nation and the national culture, a shift from the disposition to take it for granted; possibly a critical distance to it" (89). Focussing on the structure of transnational connections, Hannerz differentiates between transnationalism and globalization, considering that the term transnational designates boundary crossings that do not necessarily extend across the entire world. Thus, the term transnationalism has a narrower conceptual sphere than globalization, encompassing connections between actors different from nation-states, i.e. individuals, groups, business enterprises, etc. 
Transnationalism denotes "processes by which immigrants forge and sustain multi-stranded social relations that link together their societies of origin and settlement" (Basch et al. 2003, 7). This theoretical perspective redefines immigrants as transmigrants, i.e. immigrants who build social fields that cross geographic, cultural and political borders by their engagement in networks of relationships that connect them to two or more nation-states simultaneously (Basch et al. 2003, 7).

Although the interconnectedness afforded by globalization facilitates transnational patterns, transnationalism is not a new phenomenon, since migrants have always maintained certain types of connections with their families. Among the features of old transnationalism, Vertovec mentions the existence of strong emotional ties between immigrants and their countries of origin, return migration, back-and-forth movements between the two contexts, chain migration facilitated by long-distance networks, and ongoing communication between immigrants and their families especially via letters (Vertovec 2009, 14). Very recent studies on transnational family communication (Gonzalez and Katz 2016) also register the gradual shift in the fabric of cross-border communication strategies, directly linked with the evolution of communication technologies. Consequently, family continuity along transnational lines was initially maintained by letter writing, followed by international phone calls and eventually by digital ICT-s (Gonzalez and Katz 2016, 2691).

The novel dimension of transnationalism lies in the enhanced intensity and range of circular flows (of persons, goods, information, symbols) generated by international labor migration (Vertovec 2009, 1314). While transnational social spaces are not new phenomena (Pries 2003, 8), their novel dimension is rendered by the migrants' enhanced ability to travel back and forth between homes, discarding the diasporic connotations of absence, loss and alienation (Ashcroft 2010, 75). Due to technological innovations in communications and transportation, "networks of transnational identification" have become more important in the shaping of diaspora identities. Thus, diasporas are at once global and local, they signal processes of multi-locality across geographical cultural and psychic boundaries (Brah 1996, 21). According to Clifford, the transnational connections activated via globalization processes are conceptualized as lateral axes of diaspora (Clifford 1994, 318).

\section{Transnationalism and diaspora}

The classical definition of diaspora implies a sense of irremediable rupture with one's homeland paralleled by a wish to return to it and a sense of alienation in the host country. At the same time, diaspora formation is conditioned by coercive elements at home that enforce departure (political 
repression, starvation, etc.) (Meinhof and Triandafyllidou 2006, 200, 204). According to various writers and critical theorists, the experience of displacement is characterized by a fundamental tension between something that is forever lost and the advantages of cultural transplantation. Feelings concerning the diasporic condition seem to express a shared opinion according to which exile implies a state of in-betweenness, a simultaneous belonging and not-belonging, an alternation of losses and gains. According to E. Said: "Exile is strangely compelling to think about but terrible to experience ... The achievements of exile are permanently undermined by the loss of something left behind forever" (Said 2000, 173). Stuart Hall also mentions the ambiguity of exile, when asked about the way in which he defines himself in relation to Jamaica (his birthplace) and England. Hall emphasizes the immigrant's ability to negotiate cultural difference from the multiple perspectives of a "familiar stranger": "I know both places intimately, but I am not wholly of either place. And that's exactly the diasporic experience, far away enough to experience the sense of exile and loss, close enough to understand the enigma of an always-postponed arrival" (Hall 1996, 490). For Madan Sarup, exile is linked with the process of self-knowledge enabled by the clash with cultural Otherness. In his opinion, the paradox of displacement is represented by the fact that the journey abroad makes one readjust his/her relationship with home (Sarup 1996).

Relying on a diasporic interpretation of migration processes, the traditional approach to migration regarded displacement as a "unidirectional movement... a permanent change of home place" (Gustafson 2008, 68) triggered by push and pull factors. Studies produced within this trend employed methodological nationalism that defined migration as a movement from one nation-state to another and focussed on the immigrants' integration within the receiving country (Gustafson 2004, 68). Between the 1920's and the early 1990's, migration research focused on the immigrants' adjustment to the host countries, overlooking ways in which they continued to relate to their countries of origin (Vertovec 2009, 14). Going beyond this manner of analysis, the transnational outlook on migration considers both the sending and the receiving countries, stressing the relationships between them in the form of interactions across national borders. This direction of research highlights the role of migration networks constituted through transnational interpersonal relationships. In accounting for patterns of transnational migration, this vista intersects with theories of globalization that foreground the interconnectedness of places and nation-states (Gustafson 2004, 68). 


\section{Transnational communication}

While communication between immigrants and their families is not a new phenomenon, recent developments in communication technologies have accelerated the rhythm of these interactions, as well as the individuals' perception of physical distances. Consequently, the contemporary availability of various forms of transportation and communication technologies has the potential to "reconfigure social networks by both disconnecting and reconnecting them in complex ways" (Larsen et al. 2006, 1). Relying on this observation, the analysis investigates patterns of transnational connectivity afforded by various means of communication available to the Romanian protagonist. At the same time, the discussion stresses manners in which transnational ties both connect and disconnect members of the Romanian family across multiple borders. The discussion employs the notion of network capital in order to account for the various types of transnational networks maintained by Mona with her family. By network capital, Larsen et al. refer to:

cars, motorcycles, season tickets, phones, mobile phones, internet access points, and so on, showing how such capital is necessary for organizing and orchestrating networks especially of those ties that live beyond the reach of daily or weekly face-to-face relations. This form of capital makes the world spatially and temporally smaller by affording long bridges and fast connections between geographically dispersed people, partly because imaginative, virtual and communicative travel allows people to be in a sense in two or more places at once" (Rădulescu 2008 A, 4; emphasis added).

In the work analyzed, network capital is represented by the characters' ability to make long distance telephone calls and access TV and radio transmissions. Relying on these theoretical categories, I will examine ways in which communicative travel and imaginative travel intersect, establishing whether they can function as substitutes for or complementary to physical travel. Most of the sociological studies of contemporary migration have underscored the reality of "autonomous, free-floating individuals" (Larsen et al. 2006, 11). Their focus on fluidity implied the overlooking of "relational economies of commitments and obligations to family members, partners and friends that connect people and their networks" (Larsen et al. 2006, 11). Considering the insufficient body of research on linking mechanisms, this analysis introduces an original dimension by discussing how transnational networks both reinforce and dissolve family configurations.

According to recent trends in transnational research, novel forms of enhanced mobility affect the fabric of daily life, interfering with family structures. Itzigshon and Saucedo-Giroguli define linear transnationalism as the ensemble of practices that link immigrants to their families and 
places of origin (2005, 899). The transnational dimension intersects with the domestic sphere of family and the household, which renders the family a flexible transnational space (Briggs et al 2008, 18). Lima's socio-anthropological perspective establishes that the transnational ties consolidate family coherence, despite distance, as they determine "transnational experiences to form a fluid continuum, rather than a radical divide compartmentalizing life into two separated worlds" (Rădulescu $2008 \mathrm{~A}, 91$ ). Lima also attempts to capture/render the role of transnational families at a symbolic level, considering the cultural consequences of the ties that span several borders:

\begin{abstract}
... the transnational family is also a vehicle for the circulation and fusion of customs, practices, habits, forms of consumption, and expectations. Transnational families are therefore vehicles - better yet, agents - for both material exchanges and the creation, re-creation, and transformation of cultures. Such families are thus also important elements in the creation and survival of transnational social spaces (Rădulescu 2008 A, 91; emphasis added).
\end{abstract}

Interestingly, the intersections between transnational regimes of mobility and family structures transform families into creative cultural agents. The circulation of cultural values across physical borders contributes to the emergence of new cultural meanings that are reshaped by all family members, whether in the home country or abroad. While Lima associates transnational families with a creative potential, Ong presents a less optimistic scenario, emphasizing the possibility of family dissolution in a transnational context. Thus, she considers that transnational relocation dictated by capital accumulation entails unfortunate consequences for family patterns, such as "little emotional support, disrupted parental responsibility, strained marital relations and abandoned children" (Rădulescu 2008 A, 128).

\title{
7. Communicative travel: Phone calls
}

Train to Trieste presents communicative travel by phone call conversations as an occasional mechanism of maintaining transnational family connections. The dialogue between the displaced character, Mona, and her parents is framed by the characters' awareness of an omnipresent communist censorship. The Romanian Securitate created an impressive array of monitoring mechanisms meant to detect any individual manifestations/gestures that carried undermining connotations. In order to scrutinize the people's private lives, the Securitate relied both on informers and on recording conversations by planting microphones in a suspect's apartment. Various types of microphones - with or without batteries - were inserted either into the walls of the apartments or in banal 
objects such as ashtrays and various items of furniture (Deletant 2001, 159-210). This looming presence of the Securitate undermines the possibility of an accurate transfer of information, also emphasizing the alienating effects that distance can have upon family relations. Mona makes her first phone call home when in Rome, after she initiates the procedures for obtaining refugee status. As she hears her parents' voice at the end of the line, Mona experiences a sensation of proximity, as is she were a part of the Romanian background. The phone conversation enables Mona to feel close to her parents, as if transposed into the familiar setting of her native city:

\begin{tabular}{|c|c|}
\hline $\begin{array}{l}\text { English } \\
\end{array}$ & Romanian \\
\hline $\begin{array}{l}\text { My mother answers and her voice } \\
\text { strangles with emotion and tears. I } \\
\text { realize I've just awakened her. A new } \\
\text { gray day is starting in the little } \\
\text { Bucharest apartment; the making of soy } \\
\text { coffee, taking crowded buses to go to } \\
\text { work, looking over your shoulder to see } \\
\text { if someone is following you. She asks } \\
\text { me timidly if I am fine. I tell her, Yes, I } \\
\text { am doing very well. My father gets on } \\
\text { the phone, and I'm relieved he isn't } \\
\text { arrested or hiding somewhere. He is } \\
\text { there next to my mother, who's } \\
\text { probably wearing rollers in her hair. I } \\
\text { can hear him smoking as we talk, with } \\
\text { short furious puffs. We can't say much; } \\
\text { we assume their phone is tapped. I can't } \\
\text { give any names, addresses. I just say, } \\
\text { It's getting cold up here. I tell them, I } \\
\text { miss you so much. We hang up. I sit on } \\
\text { the little chair next to the phone in } \\
\text { Marina's apartment. I think of how } \\
\text { much of me is gone forever (Rădulescu } \\
\text { 2oo8 A, 174-175) }\end{array}$ & $\begin{array}{l}\text { Mama mea răspunde si vocea îi tremură } \\
\text { de emoție şi lacrimi. İmi dau seama că } \\
\text { tocmai am trezit-o. O altă zi întunecată } \\
\text { începe în micul apartament din } \\
\text { Bucureşti: făcutul cafelei din năut, } \\
\text { mersul cu autobuzul supraaglomerat } \\
\text { până la serviciu, privitul înapoi peste } \\
\text { umăr ca să vezi dacă te urmăreşte cineva. } \\
\text { Mă întreabă timid dacă sunt bine. Ii } \\
\text { spun ca da, sunt foarte bine. Tata vine la } \\
\text { telefon şi mă simt uşurată că nu este } \\
\text { arestat sau nu se ascunde pe undeva. } \\
\text { Este acolo, lângă mama, care probabil } \\
\text { are bigudiuri în păr. Îl aud cum fumează } \\
\text { în timp ce vorbim, cu pufăituri scurte şi } \\
\text { furioase. Nu putem vorbi prea multe } \\
\text { pentru că presupun că telefonul lor este } \\
\text { ascultat. Nu pot dau nume sau adrese. } \\
\text { Spun doar că începe să se facă frig aici. } \\
\text { Le mai spun că mi-e foarte dor de ei. } \\
\text { Închidem telefonul. Stau pe scăunelul de } \\
\text { lângă telefon în casa Marianei. Îmi dau } \\
\text { seama pentru prima dată cât de mult din } \\
\text { mine s-a dus pentru totdeauna } \\
\text { (Rădulescu 20o8 B, 146) }\end{array}$ \\
\hline
\end{tabular}

The impression of nearness afforded by communicative travel reconnects Mona with her parents' daily routines, with familiar flavors and sounds as well as the disturbing aspects of life under the communist regime. She can imagine the city's dull atmosphere permeated by the peoples' harsh living conditions and fear for their safety. Despite the distressing effects of this reconnection, this episode also foregrounds the transcendent capacity of communicative travel by which Mona manages to alleviate the pain of separation. At the same time, the character's ability to become connected with the Romanian context from a distance is 
paralleled by the invisible presence of censorship that limits the characters' communication to a few coded exchanges. Although their dialogue is imbued with unspoken emotions, the fact that they cannot freely express their feelings intensifies their awareness of the gap that separates them. Mona's feelings of her own incompleteness entail the perception of irremediable loss generated by the decision to live outside Romanian borders, in exile.

Another dimension of communicative travel in Train to Trieste is illustrated by the phone calls made by Mona from America to Romania. The author chooses to mention this type of communication only once, implying that these conversations across distance entail a uniform pattern, given their repetitive nature induced by the characters' fear of surveillance. As she contacts her parents in Romania, Mona is constantly aware of the Securitate's invisible presence that monitors their conversations. The continuity of the Secret Police's supervising practices generates the uniformity of the characters' transatlantic dialogues, that appear as monotonous instances dominated by fear and longing:

\begin{tabular}{|c|c|}
\hline English & Romanian \\
\hline $\begin{array}{l}\text { The conversations with my parents } \\
\text { across the ocean are strained and } \\
\text { interrupted by long pauses during which } \\
\text { all I can think about is the expanse of the } \\
\text { ocean that separates us. The ocean that } \\
\text { moves in its green immensity: the fierce } \\
\text { sharks, the silvery dolphins, the algae, } \\
\text { and myriad-colored fish floating in } \\
\text { rainbows. I am startled from my reverie } \\
\text { when my mother asks something simple } \\
\text { like 'How do you like your classes?' There } \\
\text { is a bulky lump of something stuck in my } \\
\text { throat. It takes me a while to answer } \\
\text { because I don't want to cry on the phone } \\
\text { while I am speaking with my mother who } \\
\text { is probably also trying not to cry. The } \\
\text { code question: Did you get the red } \\
\text { shoes? which means Were you able to do } \\
\text { anything to obtain a passport to } \\
\text { America? receives the same whispered } \\
\text { negative from my mother every single } \\
\text { time (Rădulescu 2oo8 A, 2oo). }\end{array}$ & $\begin{array}{l}\text { Conversaţiile telefonice cu părinții mei } \\
\text { sunt forțate şi întrerupte de pauze lungi } \\
\text { pe parcursul cărora nu mă gândesc } \\
\text { decât la întinderea oceanului care ne } \\
\text { separă. Oceanul mişcător în imensitatea } \\
\text { lui verde: rechinii fioroşi, delfinii } \\
\text { argintii, algele şi miriadele de peşti } \\
\text { colorați plutind ca nişte curcubee. Imi } \\
\text { revin din reverie când mama întreabă } \\
\text { ceva simplu ca de exemplu: “Îți plac } \\
\text { orele?" Ceva parcă îmi stă în gât. Îmi ia } \\
\text { ceva timp să-i răspund pentru că nu } \\
\text { vreau să plâng la telefon în timp ce } \\
\text { vorbesc cu mama care probabil că face } \\
\text { acelaşi lucru, încearcă să nu plângă. } \\
\text { Întrebarea cod: “Ți-ai luat pantofii } \\
\text { roşii?" care înseamnă ai putut obține } \\
\text { paşaportul pentru America? primeşte } \\
\text { de fiecare dată acelaşi răspuns şoptit, } \\
\text { negativ, din partea mamei mele. } \\
\text { (Rădulescu 2oo8 B, 168). }\end{array}$ \\
\hline
\end{tabular}

The unreliable nature of these transnational networks of communication hinders the characters' ability to interact, and Rădulescu seems particularly interested in summoning the idea of physical distance that causes the family's separation. Mona's detailed account of the ocean 
is meant to underscore its specificity as a specific space interposed between Mona and her homeland. In this context, the Atlantic appears as a natural border whose impressive dimensions stress the feelings of estrangement between the Romanian refugee and her parents. The characters' sadness provoked by their mutual longing is suggested by their efforts to hide their tears. Their obvious melancholy along with the necessity to use coded sentences instead of free conversations indicate the perception of an overall feeling of separation despite the possibility to hear their voices across physical distances.

These two examples of linear transnationalism as communicative travel illustrate the feeling of proximity facilitated by this form of transnational contact. However, the characters' sensation of closeness perceived as they speak on the phone is undermined by the Secret Police's looming surveillance. This interfering element indicates Mona's and her parents' different locations behind and beyond the Iron Curtain, which underscores the separatist implications of national borders. As a conclusion, the characters' ability to stay in touch by maintaining transnational connections is paralleled by the enduring effects of physical and political borders that keep them apart.

\section{Imaginative travel - TV and Radio transmissions}

The 1989 historical episode that marks the fall of Romania's communist regime is also rendered in Train to Trieste. The Romanian Revolution started in Timişoara, a city located in the Western part of Romania, in the proximity of the Hungarian and, at that time, Yugoslav borders. The area is characterized by ethnic diversity, being populated by Hungarians, Germans and Serbs. The street protests were initially motivated by the population's revolt against the persecution of Lászlo Tőkés, a Hungarian pastor of the Calvinist Church, who had the courage to speak up against the regime. Given the brutal repression of these manifestations, the protests acquired larger proportions, gradually spreading all over the country. On 21 December 1989, Ceauşescu tried to appease the population by organizing one of his notorious "meetings" where people had to mimic their adoration for the communist leader. Despite the promises of social reforms formulated by Ceaussescu, the population rebelled, uttering cries for freedom. Realizing that they were losing ground, Ceaussescu and his wife Elena arranged their escape by helicopter and car (Livezeanu). After being located and caught, on 25 December 1989, they underwent a "perfunctory" (Livezeanu), "hurried" (Duque 2011) trial. This offhand juridical procedure was presided over by a Military Council that accused the Ceaussescus of crimes against the Romanian population. The couple were sentenced to death and executed immediately via firing squad (Duque 2011). 
An entire chapter of Train to Trieste entitled "Execution on State Street" presents the impact of the Romanian Revolution on Mona, who witnesses the Ceaussescu couple's death by means of live TV (CNN) transmissions in Chicago. The first-person narrative voice presents the Ceausescu couple before, during and after their execution. The minute depiction of these events starts by including information about the setting of the Ceaussescu's trial, "a dimly lit office" (Rădulescu 2008 A, 230)/ "la un birou slab luminat” (Rădulescu 2008 B, 194). After introducing the gloomy canvas of the news, the narration provides specifics about the gestures of the two convicts, rendering their frustration and anger beyond the screen: "Ceaussescu bangs his fist on the table. Elena stares blankly in front of her" (Rădulescu 2008 A, 231)/ "Ceauşescu loveşte cu pumnul de masă. Elena se uită derutată" (Rădulescu 2008 B, 194). The unfolding of the events perceived by Mona as she watches the CNN images involves an alternation of image descriptions and her own reflections induced by these images. As Mona registers the couple's being dragged before a firing squad in a "macabre yard" (Rădulescu 2008 A, 231)/ "curte macabră" (Rădulescu $2008 \mathrm{~B}, 194)$, she meditates upon the unpredictable turns of history:

\begin{tabular}{|c|c|}
\hline English & Romanian \\
\hline $\begin{array}{l}\text { Nicolae and Elena, who watched us in } \\
\text { our most intimate moments, whose } \\
\text { secret police kept us terrorized and } \\
\text { compliant, those two people who had us } \\
\text { herded into squares and made us stand } \\
\text { for hours in the sun, the rain, the snow, } \\
\text { so they could listen to us cheering for } \\
\text { them, are being dragged by angry } \\
\text { Romanians out into what seems to be a } \\
\text { wooded yard somewhere on the outskirts } \\
\text { of Bucharest (Rădulescu } 2008 \mathrm{~A}, 231 \text { ). }\end{array}$ & $\begin{array}{l}\text { Nicolae şi Elena, care ne-au privit în } \\
\text { cele mai intime momente ale noastre, a } \\
\text { căror poliție secretă ne-a ținut supuşi } \\
\text { sub teroare, acei doi oameni care ne } \\
\text { țineau adunați în piețe şi ne făceau să } \\
\text { stăm ore în şir în soare, în ploaie, în } \\
\text { zăpadă ca să ne audă cum îi aclamăm, } \\
\text { sunt târâți de români supărați în ceea ce } \\
\text { pare o curte împădurită, undeva la } \\
\text { periferia Bucureştiului. (Rădulescu } \\
\text { 2008 B, 194). }\end{array}$ \\
\hline
\end{tabular}

The profusion of details that surface in Mona's perception minimizes the separatist effects of physical distance, suggesting the character's urge to connect with the homeland setting. Mona's perception of the 1989 Romanian events involves a high degree of involvement in the occurrences displayed on the screen. Mona's strong adherence to the Romanian realities may be explained by the fact that she has her whole family in Romania and is therefore eager to maintain her relations to her homeland. The depth of these emotional ties makes Mona feel connected with the space of her birth. Therefore, she is intensely affected by these major historical changes that will have a significant impact upon her family's and her country's destinies. Another explanation for Mona's acute interest in Romanian political events is her family's background of dissident activities, namely her father's adherence to an illegal group of 
anti-communist orientation Since she experienced direct threats from the Secret Police in Romania, Mona's life in Romania was strongly affected by the communist regime precisely because of her father's anti-communist stance. However, as she witnesses Ceausescu's death on TV, the Romanian expatriate cannot salute this event, despite her background of communist persecution:

\begin{tabular}{ll}
\hline \multicolumn{1}{c}{ English } & \multicolumn{1}{c}{ Romanian } \\
\hline How odd - instead of the bone-deep & Ce ciudat - in loc de satisfacția maximă \\
satisfaction, the limitless joy, I always & şi bucuria fără limite pe care \\
thought I'd be feeling when this & $\begin{array}{l}\text { întotdeauna am crezut că le voi simti } \\
\text { moment came, all I feel is pity and }\end{array}$ \\
când acest moment va veni, tot ceea ce \\
disgust (Rădulescu 2008 A, 231). & 2008 B, 195) \\
\end{tabular}

The fact that Mona dedicates moments of reflection upon watching the "full-fledged bloody revolution played and replayed on the television set” (Rădulescu, Train to Trieste 231)/ "O revoluție sângeroasă reluată din nou şi din nou la televizor" (Rădulescu, Trenul de Trieste 195) reveals her concern for the course of Romanian history. This is a proof of her enduring attachment for her native country, despite the physical distance that separates her from Romania. In addition, Mona's memory of her great love, Mihai, functions as an invisible, yet strong bond with Romania, even though Mona has started a family in America. At some point, the city of Brassov is featured in the CNN footage, as one of the Romanian revolutionary cities. As she overhears its name mentioned in the news, Mona is deeply affected by this important reference to her past. The nostalgia generated by the $\mathrm{CNN}$ news transposes Mona into an imaginary itinerary back home, to the space of her first love:

\begin{tabular}{|c|c|}
\hline English & Romanian \\
\hline $\begin{array}{l}\text { An image of the city center flashes by } \\
\text { quickly, with people running alongside } \\
\text { the walls of the buildings I know so well. } \\
\text { My heart feels as if about to explode. I } \\
\text { hold on to my pregnant belly, searching } \\
\text { for balance. I can think only of Mihai. I } \\
\text { imagine quick clips of him, as if in a slide } \\
\text { show: Mihai in his room brooding and } \\
\text { smoking Carpați cigarettes furiously. } \\
\text { Mihai in the streets of Braşov, wearing } \\
\text { his hiking boots, shooting at someone. } \\
\text { Mihai in the streets of Braşov, again in } \\
\text { his hiking boots, only he is the one being } \\
\text { shot at. Mihai walking in the streets } \\
\text { carelessly, recklessly, among bullets... } \\
\text { I'm wondering what's wrong with me, }\end{array}$ & $\begin{array}{l}\text { O imagine cu centrul oraşului clipeşte } \\
\text { rapid, cu oameni care aleargă pe lângă } \\
\text { zidurile clădirilor pe care le cunosc atât } \\
\text { de bine. Îmi simt inima ca şi cum ar fi pe } \\
\text { cale să explodeze. Mă țin de pântece cu } \\
\text { mâinile ca şi cum mi-aş căuta echilibrul. } \\
\text { Nu mă pot gândi decât la Mihai. Îmi } \\
\text { imaginez filmulețe scurte cu el: Mihai în } \\
\text { camera lui meditând şi fumând nervos } \\
\text { Carpați, Mihai pe străzile Braşovului } \\
\text { încălțat cu bocancii de alpinism, trâgănd } \\
\text { în cineva, Mihai pe străzile Braşovului } \\
\text { din nou cu bocancii de alpinism, doar că } \\
\text { acum se trage în el. Mihai, plimbându-se } \\
\text { pe străzi fără grijă, nepăsător, printre } \\
\text { gloanțe... Mă întreb ce e în neregulă cu }\end{array}$ \\
\hline
\end{tabular}


why can't I feel relief? All I feel is angry and exhausted (Rădulescu 2008 A, 232233; emphasis added). mine, de ce nu pot să simt nicio uşurare. Tot ceea ce simt este supărare şi epuizare (Rădulescu 2008 B, 195-6)

Mona's reaction to this part of the $\mathrm{CNN}$ footage illustrates the transgressive implications of linear transnationalism, that has the potential to cancel the separatist effects of physical frontiers. Mona's state of intense emotion suggests the strength of her connection with Romania that has also been maintained by her commitment to Mihai. While her pregnancy indicates the character's determination to start a new family, distinct from her Romanian one, Mona's imaginary encounter with Mihai in Braşov suggests her impulse to transcend spatial and temporal boundaries. The repeated invocations of Mihai illustrate the character's deep longing to reconnect with her pre-emigration life. At the same time, her feelings of anger and exhaustion suggest the challenge of having to bear the pain of estrangement generated by the restrictions on travel in countries behind the Iron Curtain. Mona's longing to return home reveals the strong emotional ties between her and her country of origin which suggest the character's belonging to the category of old transnationalism (Vertovec 2009, 14). A further proof of Mona's longing to reconnect with her homeland is the dream/nightmare of return that she has soon after watching the Romanian Revolution on TV. However, this imaginary homecoming involves dark feelings of entrapment, fear and desperation:

\begin{tabular}{|c|c|}
\hline English & Romanian \\
\hline $\begin{array}{l}\text { I am back in Bucharest, lost in a district } \\
\text { of factories on a gray November } \\
\text { afternoon. There are no people in the } \\
\text { streets. In my dream, I have the memory } \\
\text { of America, of Chicago... But this is only } \\
\text { a memory, and I know I will never be able } \\
\text { to get out again. That's it, it is all over. } \\
\text { They're going to get me now. I won't be } \\
\text { able to leave again, not ever, ever again. } \\
\text { Why, my God, did I ever come back? I } \\
\text { don't even know why I'm back in } \\
\text { Bucharest. Maybe to get my grade book } \\
\text { from the university, or maybe to see } \\
\text { Mihai. But Mihai doesn't exist any } \\
\text { longer. He was crushed in the } \\
\text { earthquake, under the building where } \\
\text { they make cream pufs. } \\
\text { (Rădulescu 20o8 A, 234) }\end{array}$ & $\begin{array}{l}\text { Sunt din nou în Bucureşti, pierdută } \\
\text { intr-un cartier industrial într-o după } \\
\text { amiază gri de noiembrie. Nu sunt oameni } \\
\text { pe străzi. În visul meu, am amintiri } \\
\text { despre America, despre Chicago ... Dar } \\
\text { aceasta este doar o amintire şi ştiu că } \\
\text { niciodată nu voi mai putea să plec din } \\
\text { nou. Asta e, totul s-a sfârşit. Mă vor } \\
\text { prinde acum. Nu voi mai putea pleca } \\
\text { niciodată. De ce, Doamne, m-am întors? } \\
\text { Nici măcar nu ştiu de ce m-am întors în } \\
\text { Bucureşti. Poate pentru a-mi lua foaia } \\
\text { matricolă de la universitate, sau poate ca } \\
\text { să-l văd pe Mihai. Dar Mihai nu mai } \\
\text { există. A fost strivit într-un cutremur, sub } \\
\text { o clădire unde se fac eclere. } \\
\text { (Rădulescu } 2008 \mathrm{~B}, 197 \text { ). }\end{array}$ \\
\hline
\end{tabular}

The native city to which Mona returns in her dream is far from representing an idealized version of her native space. Permeated by a gloomy, industrial atmosphere, Bucharest embodies the idea of a 
communist prison that leaves Mona no chance of escape. In this imaginary journey, Mona presents a perspective reversed from that of her actual life, as it is America that becomes the target of her nostalgia. The character's disappointment while back home seems particularly stirred by Mihai's absence from the familiar setting of their love. Mona's imaginary return becomes a nightmare that reminds her of the entrapment experienced within the confines of communist Romania. The character's longing for homeland reconnection is an expression of her exilic yearning that can be assuaged only in Mona's imagination. In this case, imaginative travel by means of TV broadcast has the potential to alleviate the pain of homeland separation, as it transposes Mona into the events on the screen. At the same time, the imaginary nature of this journey and the altered image of the homeland, mark the alienating effects of physical and temporal distance that modifies the familiar configuration of Mona's preemigration setting. These overlapping effects of linear transnationalism as imaginative travel reveal the intersection between diasporic and transnational parameters. On the one hand, the TV broadcast has the potential to transcend the implications of physical borders enabling Mona to feel transported elsewhere. On the other hand, Mona's transnational journey is possible only as an imaginary return journey to an unwelcoming homeland. These facts suggest that the transcending dimension of imaginative travel intersects with diasporic connotations of longing and impossible reconnection.

\section{Radio transmissions behind the Iron Curtain}

At this point, it is worth mentioning that although the Romanian population was isolated within Romania's national borders, people could get an idea about the Western world, via their obstructed, yet frequent access to foreign radio. More specifically, the Romanians' ability to listen to national news from outside sources suggests that despite communist Romania's closed borders, its people were engaged in a transnational regime of communicative travel that connected them with the Free World. The main ideas spread by Radio Free Europe included Romania in a regime of imaginative travel in the sense that they created an (otherwise) impossible connection between a communist society and a non-communist space. By presenting the existence of an anti-communist world situated beyond the physical boundaries of the Soviet empire (Puddington 2000, xviii), Radio Free Europe opened an imaginary path to freedom. Hence, transnationalism in communist Romania may be conceptualized as a means of resisting the oppressive forces of the nation-state in the absence of the citizens' relocation. I would argue that transnationalism in the form of imaginative travel was a means of undermining the authority of the communist regime/state from within. Even before the Revolution, 
the Romanian population satisfied its need for accurate information by relying on underground channels of communication from Western countries. Although Romanians had access to several foreign radio stations, Radio Free Europe enjoyed a special status among them. While BBC was appreciated for its professional journalism, and the Voice of America for its programs about American culture, Radio Free Europe was singled out by its role of a democratic opponent to the communist regime (Puddington 2000, 5). Its special purpose was to change the political system of foreign countries by broadcasting about the internal situations of those respective nations (Puddington 2000, 5-6). The most important agent that located communist Romania on a transnational axis of communication was Radio Free Europe, an international radio system, set up by the United States. "A pure Cold War institution” (Puddington 2000, ix), Radio Free Europe aimed to contribute to the collapse of the communist regime, being considered an efficient instrument of "American anti-communist diplomacy" (Puddington 2000, 5). It did so by functioning as a "surrogate home radio service" that offered an alternative to the official/domestic press which was monitored by the state (Puddington 2000, ix). In December 1989, Romania's enthusiasm about these political changes was paralleled by a general confusion as to the unknown forces behind this historical upheaval.

This pattern of linear transnationalism is also presented as a vital mechanism of survival in communist Romania by Rădulescu. Coming from a family of intellectuals, young Mona witnesses her father's secret struggle to undermine the communist regime. A literature professor outraged by the effects of dictatorship, Mona's father goes to regular meetings where he and his fellow poets prepare dissident actions, hoping to overthrow Ceaussescu's regime. Being trapped in an isolated nation, her father comes to regard Radio Free Europe as the single means of escaping the confines of communism. Unable to physically cross the borders of his nation-state, Mona's father undergoes a mental transgression as he listens to radio news about successful political dissenters:

\begin{tabular}{ll}
\hline \multicolumn{1}{c}{ English } & \multicolumn{1}{c}{ Romanian } \\
\hline After dinner he spends a lot of time with & $\begin{array}{l}\text { După cină îşi petrece mult timp cu } \\
\text { his head glued to his Grunding trying to }\end{array}$ \\
get clear reception of Radio Free Europe. & $\begin{array}{l}\text { încercând să prindă mai clar postul de } \\
\text { radio Europa Liberă. Mai tot timpul }\end{array}$ \\
Usually the static is overpowering, and & $\begin{array}{l}\text { programul de radio e supraîncărcat de } \\
\text { my mother screams at him to turn it the }\end{array}$ \\
hell off. But once in a while, the voices & paraziți, iar mama strigă la el să $\hat{\imath}$ \\
come in clearly, with an echo as if from a & $\hat{\imath}$ inchidă naibii odată. Dar câteodată \\
different universe; deep, conspiratorial, & vocea devine foarte clară, având un ecou \\
mentioning dissenting authors and their & ca şi cum ar veni din alt univers: adânc, \\
actions of resistance or interviewing & conspirativ, pomenind autorii disidenți \\
\hline
\end{tabular}


emigre writers about the abuses of the Romanian Party and leadership. My father's face brightens up as if in some kind of ecstasy. (Rădulescu 2008 A, 6263). şi acțiunile lor de rezistență sau luând interviuri scriitorilor emigranți în legătură cu abuzurile partidului şi ale conducerii. Fața tatălui meu se luminează ca-ntr-un extaz. (Rădulescu 2008 B, 55)

Mona's memories of her life in communism picture the habit of listening to Radio Free Europe as a family routine, especially cherished by her father. Providing a permanent connection with non-communist Europe, this radio station offers the possibility of transgressing physical borders without engaging in defection. While Radio Free Europe is perceived as a special access to a free society/dimension, the poor quality of the connection renders most of the transmissions fragmented. These parallel processes reveal the ambivalent relationship between national forces and transnational border crossing phenomena. More specifically, Mona's father listens to Radio Free Europe, clinging to the illusion of freedom to evade the communist context. At the same time, the effect of the static reminds the characters that travelling across the Iron Curtain is possible only at the level of imagination, as an interrupted dialogue. As a teenager, Mona is frustrated by the Romanians' entrapment within closed national borders, impossible to be actually transgressed: "Why doesn't Radio Free Europe help me out and make me free, what's the point of all the foolish activities if we are less and less free every day?" (Rădulescu 2008 A, 100)/ "De ce nu mă ajută Europa Liberă să devin liberă? Care-i scopul tuturor acelor activităti prosteşti dacă devenim pe zi ce trece tot mai puțin liberi?” (Rădulescu 2008 B, 85) The girl's yearning for a different life makes her regard Radio Free Europe as a useless channel, unable to facilitate her border crossing. However, anti-communist Romanians relied on these transnational broadcasts to assuage their thirst for freedom. Mona's father's unrelenting habit of listening to Radio Free Europe, illustrates the transgressive potential of linear transnationalism to transpose people into different realities:

\section{English}

... somehow he always manages to get just the right wave and capture the resonant voices that ring differently, both bolder and more real than any of our radio and television broadcasters relating news of the latest accomplishments of the Party... (Rădulescu, Train to Trieste 86; emphasis added).

\section{Romanian}

... el reuşeşte cumva să găsească exact lungimea de undă potrivită şi să capteze vocile rezonante care parcă sună altfel, mai accentuate şi mai reale decât orice post de radio sau de televiziune local care transmite ştiri despre realizările partidului... (Rădulescu, Trenul de Trieste 73) 
Mona's father perceives the content of the radio transmission as a passage into a realm of valid truths and right perspectives. His desperate attempts to acquire an adequate quality of the transmission illustrate the strong impact of the possibility to connect with the Western world across radio waves. Growing up in communist Romania, I have similar memories of my father's and grandfather's struggle to adjust the radio set in order to get the desired clarity of the transmissions. At that time, I had no idea of how important these broadcasts were to them and neither did I know that it was officially forbidden to listen to Radio Free Europe. I remember that one time, our assignment for the Romanian language class was to write ten sentences of our own choice. Being a diligent pupil, I would always do my homework and fortunately, my mother used to check it before my going to school. As she read my ten sentences, my mother asked me to erase the one that said: "My father listens to Radio Free Europe every day". As a child I did not perceive the illicit nature of this practice, but rather its normalcy in the family's daily activities. Now I realize that the urge to cross the borders of communist Romania was so strong for my parents, that they regarded Radio Free Europe as the least risky possibility to evade an oppressive context.

\section{Conclusion}

The investigation has distinguished two types of transnational networks that shape Mona's history of relocation: communicative travel as phone conversations and imaginative travel in the form of TV broadcasts and radio transmissions. The analysis has established that the transnational ties maintained by the Romanian characters reveal an interesting convergence between the spatial constraints imposed by physical borders and the fluid patterns afforded by a regime of transnationality. These connections reinforce the bond between the immigrants and their homeland, strengthening family coherence and reshaping the continuous narration of identity interrupted by their transplantation. In other words, these transnational ties provide short intervals of family proximity, annulling the transmigrants' alienation generated by their separation from their home countries. At the same time, the feeling of family closeness afforded by linear transnationalism is just a temporary illusion. When placed in a transnational regime of communication, the dynamics of the Romanian family illustrates the frail balance between the sensation of proximity and the separatist effects of national borders. One can identify Mona's diasporic longing to return to a state of family wholeness that seems lost after her departure. Therefore, Mona's possibility to preserve links with her family seems permanently undone by her perceived estrangement from her homeland after long intervals of separation. 
Dedicated mostly to family communication, these spoken interactions provide a feeling of close family connections, while emphasizing the characters' awareness of their separation. Rădulescu presents the immigrants' sense of separation as an effect of Romanian state surveillance that obstructs the possibility of unrestrained dialogue. As she speaks with her parents on the phone, Mona is deeply aware of the physical space that separates them and she simultaneously experiences communicative and imaginary travel. More specifically, when she speaks with her parents, the character feels transposed into the setting of the native country which she longs for. The analysis suggests that communicative travel functions as a mechanism of connection and disjuncture for the immigrants and their families. As she accesses channels of transnational communication, Mona achieves an illusion of proximity that annuls the alienating effects of physical and temporal separation. At the same time, her transnational ability to transgress national borders reminds her of the disconnectedness from homeland realities. The Romanian experience of communicative travel illustrates the permanent tension between national forces and transnational processes, suggesting that both dimensions are relevant in discussing transmigrant identity.

Imaginative travel is another pattern of linear transnationalism that surfaces in Rădulescu's account of transplantation. TV transmissions represent a channel of communication that keeps Mona linked with her homeland in particular ways. Hence, Mona Manoliu is strongly impressed by the live CNN footage of the Romanian Revolution. After this episode of communicative travel, Mona plunges into a pattern of imaginary travel, experiencing return to Romania in the form of a nightmare. Mona's ability to transgress the physical distance between Romania and America is paralleled by her strong longing for her homeland. This reaction illustrates that her profile is equally shaped by transnational and diasporic forces. Rădulescu's vision of immigrant identity displays diasporic longing for homeland that is partially soothed by her transnational regime. Radio transmissions represent a pattern of communicative travel that introduce a special situation that illustrates the possibility of transnational communication in the absence of relocation. More specifically, Western radio transmissions in communist Romania function as subversive forces that have the potential to undermine the official messages of the Romanian nation-state. Without crossing the borders of their communist nation, Romanian citizens rely on Radio Free Europe to maintain contact with a democratic world. This situation also illustrates the ambivalent relation between national forces and transnational processes, since the fixity of national borders is eroded by the citizens' ability to engage in patterns of imaginative travel to different 
worlds. Train to Trieste suggests that imaginative travel, whether in the form of TV or radio transmissions, reveals the intersecting axes of national identities and transnational migration. Mona's example implies the potential to annul the immovability of national borders. At the same time, these transnational channels also entail discordant elements, such as the poor quality of radio connections. The improper quality of these connections foregrounds the binding effects of the distance imposed by physical frontiers.

\section{References}

\section{Primary sources}

Rădulescu, Domnica. (2008 A). Train to Trieste. New York, Toronto: Alfred A. Knopf. Rădulescu, Domnica. (2008 B). Trenul de Trieste. Bucureşti: Editura Tritonic.

\section{Secondary sources}

Ashcroft, Bill. (2010). "Transnation," in Janet Wilson, Sandru Cristina and Welsh Lawson Sarah (ed.), Rerouting the Postcolonial, New Directions for the New Millennium. London and New York: Routledge, pp. 73-85.

Basch, Linda, Nina Glick Schiller, and Cristina Szanton Blanc. (2003). Nations Unbound: Transnational Projects, Postcolonial Predicaments and Deterritorialized Nation-States. London and New York: Routledge.

Brah, Avtar. (1996). Cartographies of Diaspora: Contesting Identities. London and New York: Routledge.

Briggs, Laura, Gladys, McCormick and Way, J. T. (2008). "Transnationalism: A Category of Analysis," American Quarterly, vol. 6o, no. 3, pp. 625-648. Accessed 3 Apr 2018.

Cazaban, Theodor. (2002). Captiv în lumea liberă. Theodor Cazaban în dialog cu Cristian Bădiliță. Cluj Napoca: Editura Echinox.

Clifford, James. (1994). “Diasporas," Cultural Anthropology, vol. 9, no. 3, pp. 302-338, doi:10.1525/can.1994.9.3.02a00040. Accessed on 3 Apr. 2018.

Croitoru, Alin, Sandu Dumitru, Tudor, Elena. (2014). "The Europeanisation of Everyday Life: Cross-Border Practices and Transnational Identifications Among EU and Third-Country Citizens", EUCROSS Working Paper \# 8 March 2014, http://www.eucross.eu/cms/index.php?option=com_docman\&task=cat_view \&gid=7\&Itemid $=157$, Accessed on 21 July 2016

Deletant, Dennis. (2001). "The Securitate Legacy in Romania," in Kieran, Williams and Dennis Deletant, Security Intelligence Services in New Democracies. Studies in Russia and East Europe. 159-210. Palgrave Macmillan, London. https://doi.org/10.1057/9781403905369_6

D.S. "Scriitoarea Domnica Rădulescu îşi lansează cartea Black Sea Twilight la Londra." HotNews.ro, 2011. https://www.hotnews.ro/stiri-cultura-9479370-scriitoareadomnica-radulescu-isi-lanseaza-cartea-black-sea-twilight-londra.htm). Accessed on 21 August 2019.

Duque, Nelson. (2011). "Inside Ceauşescu's Romania: An Unquestionably Efficient Police State," The View East, Central and Eastern Europe, Past and Present. 
nd., https://thevieweast.wordpress.com/2011/07/21/ inside-ceausescusromania-an-unquestionably-efficient-police-state/, Accessed on 11 July 2016.

Gonzalez, Carmen, Katz, S. Vikki. (2016). "Transnational Family Communication as a Driver of Technology Adaptation," International Journal of Communication, vol. 10, pp. 2683-2703, ijoc.org/index. php/ijoc/article/viewFile/5321/1673. Accessed on 3 Aug. 2016.

Gustafson, Per. (2004). "More or Less Transnational: Two Unwritten Papers," in Frykman Povrzanovic Maja. (ed.), Transnational Spaces: Disciplinary Perspectives. Malmo: Malmo University Press, pp. 64-76.

Hall, Stuart. (1996). "The Formation of a Diasporic Intellectual: an interview with Stuart Hall by Kuan-Hsing Chen,” in Morley, David and Chen, Kuan-Hsing (eds.), Critical Dialogues in Cultural Studies. London \& New York: Routledge, pp. 484503.

Hannerz, Ulf. (2001). Transnational Connections, Culture, People, Places. London and New York: Routledge.

Itzigsohn, Jose and Silva Saucedo-Giorguli. (2005). "Incorporation, Trans-nationalism, and Gender: Immigrant Incorporation and Transnational Participation as Gendered Processes," IMR, 39(4): 895-920. doi.org/10.1111/j.1747-73792005. tbo0293.x. Accessed on 25 July 2016.

Larsen, Jonas, John Urry and Kay Axhausen. (2006). Mobilities, Networks, Geographies. Hampshire and Burlington: Ashgate.

Lima, Herrera Fernando. (2003). "Transnational Families, Institutions of transnational social space," in Ludger Pries (ed.), New Transnational Social Spaces, International Migration and Transnational Companies in the early $21^{\text {st }}$ century. London and New York: Routledge, pp. 77-93.

Livezeanu, Irina. "The Unique Experience of Romania," Making the History of 1989. University of Pittsburgh, Pennsylvania. https://chnm.gmu.edu/ 1989/exhibits /unique-experience-of-romania/introduction, Accessed on 11 July 2016.

Meinhof, Hanna Ulrike and Triandafyllidou Anna (eds.). (2006). Transcultural Europe, Cultural Policy in Changing Europe. Palgrave Macmillan.

Ong, Aiwha. (2006). Flexible Citizenship: The Cultural Logic of Transnationality. Durham and London: Duke University Press.

Oprescu-Şerban Teodora, Oprescu-Şerban George. (2012). "Overview of Romanian Emigration to America during Communism and Postcommunism: Cultural Dimensions of Quality of Life," International Journal of Humanities and Social Science, 2(23): 45-53. http://www.ijhssnet.com/journals/Vol_2_No_23_ December_2012/6.pdf, Accessed on 21 July 2016.

Pries, Ludger. (2003). New Transnational Social Spaces, International Migration and Transnational Companies in the Early 21 ${ }^{\text {st }}$ Century. London and New York: Routledge.

Puddington, Arch. (2000). Broadcasting Freedom, The Cold War Triumph of Radio Free Europe and Radio Liberty. Lexington, Kentucky: The University Press of Kentucky.

Rădulescu, Domnica. (2008). Interview in Revista Flacăra. "Domnica Rădulescu, înapoi în România cu trenul de Trieste.” December 10, 2008, http://revistaflacara. ro/domnica-Rădulescu-inapoi-in-romania-cu-trenul-de-trieste/, Accessed on 24 October 2015.

Said, Edward. (2000). Reflections on Exile and Other Essays. Cambridge, Mass.: Harvard University Press.

Sarup, Madan. (1996). Identity, Culture and the Postmodern World. Edinburgh: Edinburgh University Press. 
"The Ears of the Romanian Secret Police: How the "Securitate" Used Microphones." Tour of Communism. A Journey through the Communist History of Bucharest, Romania. 2014. https://tourofcommunism.com/ 2014/01/o7/the-ears-of-theromanian-secret-police-how-the-securitate-used-microphones/, Accessed on 20 August 2019.

Tololyan, Khachig. (1996). "Rethinking Diaspora(s): Stateless Power in the Transnational Moment." Diaspora: A Journal of Transnational Studies, Project MUSE, 5(1): 3-36, doi:10.1353/dsp.1996.0000. Accessed on 15 Mar. 2017.

Vertovec, Stephen. (2009). Transnationalism Key Ideas. London and New York: Routledge. 